A GLOSSARY OF MORPHOLOGY 


\section{TITLES IN THE SERIES INCLUDE}

Peter Trudgill

A Glossary of Sociolinguistics

0748616233

Jean Aitchison

A Glossary of Language and Mind

0748618244

Alan Davies

A Glossary of Applied Linguistics

0748618546

Geoffrey Leech

A Glossary of English Grammar

0748617299

Tony McEnery, Andrew Wilson and Paul Baker

A Glossary of Corpus Linguistics

0748620184

Alan Cruse

A Glossary of Semantics and Pragmatics

0748621113 


\title{
A Glossary of Morphology
}

\author{
Laurie Bauer
}

Edinburgh University Press 
(C) Laurie Bauer, 2004

Transferred to Digital Print 2012

Edinburgh University Press Ltd

22 George Square, Edinburgh

Typeset in Sabon

by Norman Tilley Graphics, Northampton

Printed and bound by CPI Group (UK) Ltd, Croydon, CR0 4YY

A CIP record for this book is available from the British Library

ISBN 0748618538 (paperback)

The right of Laurie Bauer

to be identified as author of this work has been asserted in accordance with the Copyright, Designs and Patents Act 1988. 